MACIEJ J. NowaK

Zachodniopomorski Uniwersytet Technologiczny w Szczecinie

\title{
Goleniowski Park Przemysłowy jako przykład aktywnej polityki przestrzennej prowadzonej w gminie
}

\section{WPROWADZENIE}

Każda jednostka samorządu terytorialnego, w szczególności gmina, może prowadzić bierną lub aktywną politykę przestrzenną. O ile bierna polityka przestrzenna (występująca w większości polskich gmin) polega na doraźnym funkcjonowaniu bez podejmowania istotnych decyzji z inicjatywy danej jednostki samorządowej, o tyle aktywna polityka przestrzenna łączy się z funkcjonowaniem władz samorządowych jako podmiotu przyciagającego inwestycje przy wykorzystaniu zróżnicowanych instrumentów. Przykładem gminy prowadzącej aktywną politykę przestrzenną może być położona w województwie zachodniopomorskim gmina Goleniów, na terenie której funkcjonuje Goleniowski Park Przemysłowy oraz specjalna strefa ekonomiczna. I właśnie Goleniowski Park Przemysłowy oraz specjalna strefa ekonomiczna stanowią instrument rozwoju przedsiębiorczości na terenie gminy. Warto zaznaczyć, że samo założenie organizacyjnej konstrukcji parku przemysłowego nie wyczerpuje znamion definicji aktywnej polityki przestrzennej niezbędne jest również dalsze działanie władz samorządowych w kierunku odpowiedniego rozwoju parku, a co za tym idzie przedsiębiorczości na terenie gminy.

\section{ROLA PARKÓW PRZEMYSŁOWYCH ORAZ SPECJALNYCH STREF EKONOMICZNYCH} W POLITYCE PRZESTRZENNEJ

Zgodnie z art. 1.a ustawy z dnia 29 sierpnia 2003 o zmianie ustawy o finansowym wspieraniu inwestycji oraz ustawy o warunkach dopuszczalności i nadzorowaniu pomocy publicznej dla przedsiębiorców (Dz. U. z 2003, Nr 159, poz. 1537) parkiem przemysłowym jest zespół wyodrębnionych nieruchomości, w którego skład wchodzi co najmniej jedna nieruchomość, na której znajduje się infrastruktura techniczna pozostała po restrukturyzowanym lub likwidowanym przedsiębiorcy. Park przemysłowy jest tworzony na podstawie umowy cywilnoprawnej, której jedną ze stron jest jednostka samorządu terytorialnego. Daje możliwość prowadzenia działalności gospodarczej przedsiębiorcom, w szczególności małym 
i średnim, na preferencyjnych warunkach. Pierwszym parkiem przemysłowym w Polsce był założony w roku 1993 Warszawski Park Przemysłowy. Parki przemysłowe moga przybierać różne formy prawne: spółek akcyjnych, spółek z ograniczoną odpowiedzialnością, stowarzyszeń, spółek prawa cywilnego, a nawet fundacji. Wybór zależy przede wszystkim od uznania władz gminnych, a także ich możliwości finansowych, celu i zakresu planowanego przedsięwzięcia. Celem głównym parków jest współpraca pomiędzy jednostką samorządu terytorialnego a przedsiębiorcami, co może przyczynić się do podniesienia konkurencyjności danego ośrodka, zmniejszenia bezrobocia bądź też przyciągnięcia inwestorów.

W przypadku definicji parku przemysłowego niezwykle istotne obok umowy cywilno-prawnej jako podstawy funkcjonowania jest zapewnienie przedsiębiorcom preferencyjnych warunków na terenie danej jednostki samorządu terytorialnego. Preferencyjne warunki mogą polegać na pobieraniu niższych podatków, czynszów dzierżawnych itp. Formuła takiej umowy w dużym stopniu zależy od inicjatywy danej jednostki samorządu terytorialnego. Może ona również w ramach zobowiązań organizować szkolenia dla przedsiębiorców, refundować koszty zatrudnienia osób bezrobotnych bądź też ułatwiać przedsiębiorcy dostęp do środków infrastruktury technicznej. Współpraca może być także oparta na zasadach określonych w ustawie z dnia 28 lipca 2005 r. o partnerstwie publiczno-prywatnym (Dz. U. z 2005, Nr 169, poz. 1420). Przedsiębiorcy, którzy staną się stronami umowy o powołaniu (bądź przystapieniu) do parku przemysłowego, mogą otrzymać do zrealizowania zadanie publiczne (Jacyszyn, Kalinowski 2006, s. 20).

Według odmiennych zasad funkcjonują specjalne strefy ekonomiczne, dla których podstawą prawną jest ustawa z 20 października 1994 r. o specjalnych strefach ekonomicznych (Dz. U. 1994, Nr 123, poz. 600, tekst jednolity, Dz. U. z 2007, Nr 42, poz. 274. ze zm.). Zgodnie $z$ art. 2 ustawy specjalną strefą ekonomiczną jest wyodrębniona, niezamieszkana część terytorium Rzeczypospolitej Polskiej, na terenie której może być prowadzona działalność gospodarcza. Wśród celów ustanowienia specjalnej strefy ekonomicznej ustawodawca wymienia takie czynniki, jak rozwój określonych dziedzin działalności gospodarczej, zagospodarowanie istniejącego majątku przemysłowego i infrastruktury gospodarczej (co może być bardzo istotne z punktu widzenia aktywnej polityki przestrzennej), tworzenie nowych miejsc pracy bądź też zagospodarowanie niewykorzystanych zasobów naturalnych z zachowaniem równowagi ekologicznej. Ogólnie można więc powiedzieć, że cele powstania specjalnej strefy ekonomicznej przypominają cele parku przemysłowego, z tym zastrzeżeniem, że występują one w znacznie szerszym zakresie i na większą skalę. Przejawem tego jest m.in. sposób powstania strefy w postaci wydawanego rozporządzenia Rady Ministrów z wniosku ministra właściwego do spraw gospodarki w porozumieniu z ministrem właściwym do spraw rozwoju regionalnego. Co do zasady strefa ustanawiana jest na gruntach należących do „zarządzającego” (pojęcie to jest wyjaśnione poniżej), Skarbu Państwa i gminy, jednakże w przypadkach uzasadnionych ważnymi względami gospodarczymi właścicielem części strefy może być również inny podmiot. Przez ważne względy gospodarcze należy rozumieć na przykład sytuację, w której udział w strefie danego przedsiębiorcy jest istotny z ekonomicznego punktu widzenia dla całej strefy. Oczywiście, im szerszy zakres działalności gospodarczej dany przedsiębiorca prowadzi i im większym kapitałem dysponuje, w tym większym stopniu może narzucać swoje warunki w tej dziedzinie.

„Zarządzającym” specjalną strefą ekonomiczną może być wyłącznie spółka kapitałowa: czyli spółka z ograniczoną odpowiedzialnością bądź spółka akcyjna (ta druga forma prawna występuje w praktyce znacznie częściej), w których Skarb Państwa lub samorząd wojewódz- 
twa posiada większość głosów na walnym zgromadzeniu lub zgromadzeniu wspólników oraz jest uprawniony do powoływania większości członków zarządu. „Zarządzający” zajmuje się rozwojem strefy, udostępniając przedsiębiorcom składniki mienia znajdujące się na jej terenie, gospodarując składnikami infrastruktury technicznej i gospodarczej, a także zbywając przysługujące mu prawo własności gruntów lub prawo użytkowania wieczystego (jeżeli jest to zgodne ze stanowiącym rozporządzenie ministra właściwego do spraw gospodarki, zawierającego cele i środki planem rozwoju strefy). „Zarządzający” wydaje ponadto regulamin strefy, w którym określa w sposób szczegółowy zasady zarządu.

Dochody osób fizycznych i osób prawnych prowadzących działalność gospodarczą na terenie strefy są zwolnione od podatku dochodowego. Ponadto przedsiębiorcy działający na terenie strefy zwolnieni są od opłat i podatków lokalnych, jak np. podatek od nieruchomości (Olszewski red. 2005, s. 340). Na wniosek zarządzającego starosta i rada gminy mogą mu powierzyć uprawnienia do wydawania decyzji administracyjnych na terenie strefy, dotyczących przede wszystkim spraw związanych z prawem budowlanym (np. o pozwoleniu na budowę czy w sprawach ustalenia warunków zabudowy i zagospodarowania dotyczących terenów położonych w strefie). Dostęp przedsiębiorcy do działalności gospodarczej prowadzonej na terenie strefy uwarunkowany jest otrzymaniem zezwolenia wydanego przez ministra właściwego do spraw gospodarki (ustalenie zezwolenia odbywa się na podstawie przetargu lub rokowań podjętych na podstawie publicznego zaproszenia).

Obecnie na terenie RP występuje czternaście specjalnych stref ekonomicznych. Warto podkreślić, że wszystkie one powstały w latach dziewięćdziesiątych, a najstarsza została zorganizowana w roku 1995 w Mielcu. Głównym organem założycielskim większości z nich jest Skarb Państwa. Wspólnikami w podmiotach ,zarządzających” są jednak również jednostki samorządu terytorialnego, uczelnie bądź też przedsiębiorcy. Strefy, w przeciwieństwie do parków przemysłowych, nie korzystają z instrumentu prawnego, jakim jest partnerstwo publiczno-prywatne.

Warto również podkreślić, że zgodnie z traktatem akcesyjnym, wszystkie specjalne strefy ekonomiczne muszą zakończyć działalność do roku 2017. Później najprawdopodobniej w większości również przekształcą się w parki przemysłowe (taka opcja będzie dla nich najbardziej korzystna z ekonomicznego punktu widzenia).

\section{GMinA Goleniów JAKO NAJLEPSZE MIEJSCE LOKALIZACJI PARKU PRZEMYSŁOWEGO}

\section{W WOJEWÓDZTWIE ZACHODNIOPOMORSKIM}

Gmina wiejsko-miejska Goleniów jest położona w bezpośrednim sąsiedztwie gminy Szczecin, wchodząc tym samym w skład Szczecińskiego Obszaru Metropolitalnego. Gmina ma powierzchnię 443,06 km² (172,26 km² grunty rolne, $231,13 \mathrm{~km}^{2}$ grunty leśne) oraz ponad 30 tys. mieszkańców. Składa się z 52 miejscowości oraz 32 sołectw. Zajmuje tym samym piąte miejsce co do wielkości oraz siódme co do liczby ludności w województwie zachodniopomorskim. Najważniejsze funkcje gminy to przemysł, obsługa ludności oraz gospodarka żywnościowa. Od niedawna rośnie rola turystyki oraz agroturystyki. Główne branże przemysłowe to meblarska, metalowa, papiernicza oraz spożywcza. Baza ekonomiczna reprezentowana jest przez wiele różnych podmiotów gospodarczych. Jako najważniejsze ośrodki w tym kontekście można wyróżnić takie miejscowości, jak Goleniów, Kliniska, Danowo, 
Miękowo, Lubczyna, Mosty oraz Załom. Przy obwodnicy drogowej na obszarze miasta wyznaczony został park przemysłowy, na terenie którego można lokalizować dowolne usługi przemysłowe. Gmina położona jest na skrzyżowaniu ważnych szlaków komunikacyjnych, zresztą w jej obrębie jest bardzo dobrze rozwinięta infrastruktura. Dokumenty gminne wśród mocnych stron Goleniowa wyróżniają rozwiniętą infrastrukturę, dużą aktywność mieszkańców, dobrą sytuację ekonomiczną oraz znaczenie stolicy gminy o zasięgu subregionalnym. Wśród minusów wspomniano o niedostatecznym rozwoju turystyki oraz słabym tempie rozwoju budownictwa wielorodzinnego (Strategia... 1999). Szansą na polepszenie sytuacji gminy są środki z Unii Europejskiej, programy pomocowe oraz funkcjonowanie portu lotniczego. Biorąc pod uwagę położenie gminy Goleniów, jej powierzchnię oraz rozwinięty przemysł i infrastrukturę, należy stwierdzić, że jest to optymalne miejsce na prowadzenie zaawansowanej działalności gospodarczej w województwie zachodniopomorskim. Wydaje się, że zrealizowane w tym wypadku są czynniki wyodrębnione dla renty miejskiej, jak m.in. przestrzenna dostępność komunikacyjna, poziom wyposażenia w infrastrukturę techniczna, jakość istniejącego zagospodarowania.

\section{Goleniowski Park PrzemysŁowy oraz Kostrzyńsko-SŁubicka Specjalna Strefa Ekonomiczna}

Goleniowski Park Przemysłowy ma powierzchnię 305 ha przeznaczonych pod obiekty produkcyjne i usługi przemysłowe (przedmiotowo związane z przemysłem dominującym na terenie gminy Goleniów). Na terenie parku od roku 2005 funkcjonuje ponadto licząca 33,6080 ha Specjalna Strefa Ekonomiczna, będąca podstrefą Kostrzyńsko-Słubickiej Specjalnej Strefy Ekonomicznej. Na terenie parku zostały już rozpoczęte inwestycje przez przedsiębiorców zajmujących się m.in. produkcją żywności, opakowań, tapet, przyczep, naczep transportowych oraz łopat dla siłowni wiatrowych. Niewatpliwie na zainteresowanie przedsiębiorców duży wpływ ma położenie parku i strefy na terenie Szczecińskiego Obszaru Metropolitalnego (około $35 \mathrm{~km}$ od Szczecina). Zgodnie z Programem Pomocy Regionalnej Dla Przedsiębiorców Inwestujących Na Terenie Gminy Goleniów przedsiębiorcy, którzy zainwestują na terenie gminy po raz pierwszy, zwolnieni są z podatku od nieruchomości za grunty, budynki i budowle w pierwszym roku w $100 \%$, a w drugim roku $\mathrm{w} 50 \%$. Z podatku zwalniani są również przedsiębiorcy, którzy inwestują wysoką kwotę i zapewniają określoną liczbę miejsc pracy.

Tab. 1. Warunki zwolnień przedsiębiorców od płatności podatku od nieruchomości na terenie Goleniowskiego Parku Przemysłowego

\begin{tabular}{|c|c|c|}
\hline $\begin{array}{c}\text { Kwota, którą przekracza } \\
\text { wartość nowych inwestycji } \\
\text { danego przedsiębiorcy } \\
\text { (Euro) }\end{array}$ & $\begin{array}{c}\text { Minimalna liczba miejsc pracy } \\
\text { utworzonych przez danego } \\
\text { przedsiębiorcę na terenie } \\
\text { gminy Goleniów }\end{array}$ & $\begin{array}{c}\text { Okres, na który dany przedsiębiorca } \\
\text { zwolniony jest z obowiązku } \\
\text { płacenia podatku od nieruchomości } \\
\text { na terenie gminy }\end{array}$ \\
\hline 30000 & 5 & 1 \\
\hline 50000 & 15 & 2 \\
\hline 80000 & 25 & 3 \\
\hline 100000 & 35 & 4 \\
\hline 150000 & 45 & 5 \\
\hline
\end{tabular}

Źródło: badania własne na podstawie danych uzyskanych w gminie Goleniów 
Z tabeli nr 1 wynika, że władzom gminy Goleniów w największym stopniu zależy na celach związanych z funkcjonowaniem parku przemysłowego, polegających na zwalczaniu bezrobocia oraz pozyskiwaniu inwestorów. Przy czym bardziej istotnym czynnikiem wydaje się tutaj wysokość planowanych inwestycji. Zatrudnienie danej liczby pracowników może W większym stopniu obciążyć przedsiębiorców, dlatego większa liczba obligatoryjnych pracowników pojawia się w przypadku kryteriów dłuższych ulg podatkowych, gdy przedsiębiorca zdecydowany jest na dłuższą działalność na terenie gminy.

Ulgi występują także w innych wypadkach, jak choćby przy okazji nakładów poniesionych na rozszerzenie danego przedsiębiorstwa bądź zakup środków transportowych. Ponadto należy podkreślić, że Goleniowski Park Przemysłowy (GPP) jest uzbrojony w kanalizację ściekową i sanitarną podłączoną do miejskiej oczyszczalni ścieków. GPP został wymieniony w Strategii Rozwoju Województwa Zachodniopomorskiego do roku 2020, gdzie stanowi przykład efektywnej działalności gminy.

Kostrzyńsko-Słubicka Specjalna Strefa Ekonomiczna położona jest na terenie trzech województw: zachodniopomorskiego, lubuskiego oraz wielkopolskiego, co w istotnym stopniu wpływa na możliwość wykorzystania potencjału ziem zachodnich. Na podstawie aktualnie obowiązującego rozporządzenia Rady Ministrów z dnia 5 grudnia 2006 r. w sprawie Kostrzyńsko-Słubickiej specjalnej strefy ekonomicznej (Dz. U. Nr 236 z 2006, poz. 1704 ze zm.) $)^{1}$ obejmuje ona grunty o powierzchni 1186,3803 ha i działa do dnia 31 grudnia 2020 roku. Zarządzającym strefą jest Kostrzyńsko-Słubicka Specjalna Strefa Ekonomiczna S.A. z siedzibą w Kostrzynie nad Odrą. Grunty położone na terenie strefy są w większości własnością zarządzającego, a w pozostałym zakresie własnością gmin. Zgodnie z rozporządzeniem Ministra Gospodarki z dnia 23 sierpnia 2005 r. zmieniającego rozporządzenie w sprawie planu rozwoju Kostrzyńsko-Słubickiej Specjalnej Strefy Ekonomicznej (Dz. U. $\mathrm{Nr}$ 182, poz. 1534) wśród najważniejszych celów strefy można wyróżnić: zahamowanie wzrostu bezrobocia, a następnie jego obniżenie poprzez utworzenie docelowo 10 tysięcy nowych miejsc pracy w strefie oraz jej otoczeniu, pobudzenie działalności produkcyjnej i usługowej w regionie poprzez stworzenie nowoczesnych ośrodków przemysłowych oraz dywersyfikacja działalności gospodarczej. Na podstawie regulaminu Kostrzyńsko-Słubickiej Specjalnej Strefy Ekonomicznej „zarządzający” ma m.in. prawo do wydawania w imieniu Ministra Gospodarki zezwoleń dla przedsiębiorców do działalności na terenie strefy, wydawania w pierwszej instancji decyzji dotyczących prawa budowlanego i zagospodarowania przestrzennego na terenie strefy oraz opiniowania wniosków przedsiębiorcy do organu administracji państwowej w sprawie wydawania decyzji o dopuszczalnej emisji zanieczyszczenia do atmosfery ${ }^{2}$. Szczegółowe przepisy służące określeniu warunków umożliwiających objęcie przez strefę ekonomiczną kolejnych gruntów zostały określone w rozporządzeniu Rady Ministrów z dnia 10 grudnia 2008 r. w sprawie kryteriów, których umożliwienie spełnia objęcie części gruntów specjalną strefą ekonomiczną (Dz. U. nr 224, poz. 1477).

Struktura Kostrzyńsko-Słubickiej Specjalnej Strefy Ekonomicznej jest zgodna z regulacjami ustawowymi. Zwraca uwage duży zakres swobody przy podejmowaniu decyzji,

${ }^{1}$ Przedmiotowe rozporządzenie było kilkukrotnie zmieniane, w pracy oparto się na stanie prawnym z 12 marca $2008 \mathrm{r}$.

${ }^{2}$ Szczegółowe zasady związane z udzielaniem pomocy publicznej przedsiębiorcom określono w Rozporządzeniu Rady Ministrów z 10 grudnia 2008 r. w sprawie pomocy publicznej udzielanej przedsiębiorcom na podstawie zezwolenia na prowadzenie działalności gospodarczej na terenach specjalnych stref ekonomicznych (Dz. U. 232, poz. 1548). 
jaki został przyznany ,zarządzającemu”. Niewątpliwie, podział strefy na poszczególne podstrefy znajdujące się w różnych województwach podporządkowuje interesy podstref interesom gmin, na terenie których one się znajdują. Przykładem tego jest właśnie sytuacja podstrefy znajdującej się na terenie Goleniowskiego Parku Przemysłowego.

Należy dodać, że przygotowywane jest przez Radę Ministrów kolejne rozporządzenie dotyczące Kostrzyńsko-Słubickiej Specjalnej Strefy Ekonomicznej. Zgodnie z nim strefa ma liczyć 1258,3254 ha powierzchni. Wraz z rozszerzeniem powierzchni strefy wiązać się powinno rozszerzenie powierzchni Goleniowskiego Parku Przemysłowego. Projekty rozporządzeń nie stanowią źródła prawa i mogą być wielokrotnie zmieniane w toku obrad organu wykonawczego, jednakże z wywiadu bezpośredniego uzyskanego w gminie Goleniów wynika, że docelowo powierzchnia podstrefy położonej na terenie Goleniowskiego Parku Przemysłowego powinna się rozszerzyć do ponad 64 ha. Stanowiłoby to rozwinięcie dotychczasowych tendencji.

\section{GOSPODARKA NIERUCHOMOŚCIAMI NA TERENIE Goleniowskiego Parku PrzemysŁowego}

Z punktu widzenia prowadzonych badań najbardziej istotny jest zakres stosowanych instrumentów gospodarki nieruchomościami na terenie Goleniowskiego Parku Przemysłowego, w tym sprzedaż przez gminę Goleniów gruntów przedsiębiorcom chcącym prowadzić działalność gospodarczą na terenie parku. W przypadku ogólnej gospodarki nieruchomościami gminnymi na terenie gminy Goleniów największy akcent położony jest na sprzedaż gruntów. Ma to przełożenie na funkcjonowanie Goleniowskiego Parku Przemysłowego

Tab. 2. Sprzedaż gruntów przez gminę Goleniów na terenie Goleniowskiego Parku Przemysłowego w latach 2002-2007

\begin{tabular}{|c|c|c|c|}
\hline Rok & $\begin{array}{c}\text { Liczba } \\
\text { nabywców }\end{array}$ & $\begin{array}{c}\text { Eączna sprzedana powierzchnia } \\
(\text { ha })\end{array}$ & $\begin{array}{c}\text { Łączna cena } \\
\text { sprzedanych gruntów (zł) }- \text { brutto }\end{array}$ \\
\hline 2002 & 1 & 28 & 1931180 \\
\hline 2003 & 4 & 18,93 & 1266970 \\
\hline 2004 & 2 & 8,1 & 477231 \\
\hline 2005 & 9 & 19,1 & 5894270 \\
\hline 2006 & 6 & 17,28 & 5350839 \\
\hline 2007 & 10 & 58,54 & 12581848 \\
\hline
\end{tabular}

Źródło: opracowanie własne

Z tabeli 2 wynika, że od roku 2005 zdecydowanie wzrosła liczba nabywców gruntów, co skutkowało również wzrostem cen za sprzedawane grunty i większymi dochodami gminnymi. Pomijając rok 2004, powierzchnia sprzedawanych gruntów była na zbliżonym poziomie, z wyjątkiem roku 2007, kiedy to powierzchnia sprzedawanych gruntów uległa trzykrotnemu powiększeniu. Można szacować, że w roku 2008 powierzchnia sprzedanych gruntów nie będzie już tak duża i na pewno nie przekroczy 20 ha. W tym kontekście warto zwrócić uwagę na dwie najważniejsze daty dla badanego okresu: 15 marca 2003 r. utworzono na terenie parku 15 ha Specjalnej Strefy Ekonomicznej, a 30 sierpnia 2005 r. rozszerzono podstrefę 
o kolejne 22 ha. Skutkowało to większym zainteresowaniem ze strony przedsiębiorców. Należy pamiętać, że nieruchomości są dobrem deficytowym (Kucharska-Stasiak 2006, s. 21), stąd niemożliwe jest w każdym roku powiększanie sprzedawanej powierzchni, jednakże warto podkreślić fakt, że gmina poprzez działania ukierunkowane na maksymalne rozszerzenie powierzchni podstrefy w możliwie najszerszym stopniu nastawiona jest na efektywne pozyskiwanie inwestorów. Niewątpliwie na większe zainteresowanie przedsiębiorców miało wpływ również doprecyzowanie przez gminę warunków ulg (zwłaszcza podatkowych) udzielanych na terenie parku przemysłowego.

$T a b$. 3. Średnia wartość 1 ha gruntu sprzedawanego przez gminę Goleniów na terenie Goleniowskiego Parku Przemysłowego w latach 2002-2007

\begin{tabular}{|c|c|}
\hline Rok & Wartość 1 ha gruntu brutto (zt) \\
\hline 2002 & 68970 \\
\hline 2003 & 66925 \\
\hline 2004 & 58917 \\
\hline 2005 & 308600 \\
\hline 2006 & 309655 \\
\hline 2007 & 214927 \\
\hline
\end{tabular}

Źródło: opracowanie własne

Rok 2005 jest istotnym rokiem granicznym z punktu widzenia zagadnienia przeciętnej wartości 1 ha sprzedawanego gruntu: jest tak przede wszystkim z powodu rozwoju i późniejszego powiększenia powierzchni specjalnej strefy ekonomicznej na terenie parku, co potwierdza tezę, że specjalne strefy ekonomiczne w obecnym stanie prawnym i ekonomicznym stanowią przedsięwzięcia znacznie bardziej opłacalne dla rozwoju lokalnego od parków przemysłowych. Oczywiście, jak wskazano powyżej, powołanie takiej strefy jest trudniejsze od ustanowienia parku przemysłowego, stąd też tym bardziej należy docenić działania związane z rozszerzeniem strefy.

Należy ponadto dodać, że z wywiadu przeprowadzonego w Urzędzie Gminy Goleniów wynika, że na dzień 10 września 2008 r. w Goleniowskim Parku Przemysłowym działalność gospodarczą rozpoczęło 17 przedsiębiorców, a 6 kolejnych przygotowuje się do jej rozpoczęcia.

\section{Podsumowanie}

W literaturze podkreśla się różnorakie problemy związane z gospodarowaniem nieruchomościami oraz gospodarowaniem przestrzenią w gminach. Podnosi się między innymi, że zatrudnienie w strefie zewnętrznej obszaru metropolitalnego podporządkowane jest potrzebom efektywnego wykorzystania miejsc pracy w centrach obszarów (Gontarski 1980, s. 184). Parki przemysłowe i na szerszą skalę specjalne strefy ekonomiczne mogą w pewnym stopniu modyfikować wspomnianą tendencję poprzez tworzenie nowych miejsc aktywności gospodarczej. Gminy w Polsce bardzo chętnie pozbywają się swoich zasobów gruntów, co - nieprawidłowo koordynowane - może skutkować opóźnieniami w procesach inwestycyjnych (Hrabal 2008, s. 15). Sprzedaż gruntów znajdujących się na terenie parków oraz stref 
może rozwiązywać w pewnym zakresie również ten problem. W takim układzie bowiem sprzedaż wpływa na rozwój gospodarczy danego terenu. Rozwój przedsiębiorców oraz stymulowany rozwój miejsc pracy wpływa również w istotnym stopniu na rozwój cywilizacji informacyjnej, może być instrumentem włączenia jak największej części polskiej przestrzeni do cywilizacji informacyjnej, która opiera się przecież m.in. na kapitale społecznym oraz infrastrukturze technicznej (Gaczek 2003, s. 104). Biorąc pod uwagę powyższe, należy stwierdzić szereg korzyści wynikających z funkcjonowania specjalnych stref ekonomicznych oraz parków przemysłowych.

Analiza uwarunkowań związanych z funkcjonowaniem Goleniowskiego Parku Przemysłowego i znajdującej się na jego terenie Specjalnej Strefy Ekonomicznej skłania do wniosku, że efektywne wykorzystanie organizacyjnych oraz ekonomicznych instrumentów dostępnych dla zarządzających terenami wiąże się w istotnym stopniu z uzyskaniem dużych dochodów. Dlatego wskazane jest, by zarówno specjalne strefy ekonomiczne (w pierwszym rzędzie), jak i parki przemysłowe posiadały możliwie największą powierzchnię i nastawione był na pozyskiwanie największej liczby inwestorów. Działania te stanowią istotny przykład „nowego zarządzania publicznego" (Miszczuk i in. 2007, s. 170-171). Najlepszym przykładem odpowiedniego stosowania instrumentów aktywnej polityki przestrzennej jest właśnie Goleniowski Park Przemysłowy. Należy dodać, że niniejszy park można porównywać z parkami przemysłowymi położonymi na terenie pobliskich gmin (Police, Stargard Szczeciński) i pod względem powierzchni i zakresu działań stwierdza się wyraźną przewagę GPP. Jest to uwarunkowane inicjatywą władz gminnych, przejrzystymi kryteriami funkcjonowania parku, odpowiednią akcją promocyjną oraz odpowiednim stosowaniem instrumentów zachęcających inwestorów do współpracy.

\section{Literatura}

Gaczek W.M., 2003, Zarzqdzanie w gospodarce przestrzennej, Oficyna Wydawnicza Branta, Bydgoszcz-Poznań.

Gontarski Z., 1980, Obszary metropolitalne w Polsce, PAN, Warszawa.

Hrabal A., 2008, Struktura własności a skuteczność planowania rozwoju przestrzennego, „Świat Nieruchomości", nr 63.

Jacyszyn J., Kalinowski T., 2006, Komentarz do ustawy o partnerstwie publiczno-prywatnym, Lexis Nexis, Warszawa.

Kucharska-Stasiak E., 2006, Nieruchomość w gospodarce rynkowej, PWN, Warszawa.

Miszczuk A., Miszczuk M., Żuk K., 2007, Gospodarka samorzqdu terytorialnego, Wydawnictwo Naukowe PWN, Warszawa.

Olszewski J. red., 2005, Publiczne prawo gospodarcze, Beck, Warszawa.

Strategia społeczno-gospodarczego rozwoju gminy Goleniów na lata 2000-2009, 1999, Goleniów.

\section{Goleniów Industrial Park as an example of an active spatial policy in communes}

The Goleniów Municipality is situated in the North-Western part of Poland, $35 \mathrm{~km}$ from Szczecin and $65 \mathrm{~km}$ from Świnoujście. Its total area is $444 \mathrm{~km} 2$. The population of the town of Goleniów is about 23,000 inhabitants, and the population of the municipality altogether is about 33,000. It is an industryagricultural municipality, with a domination of the furniture and wood processing, cardboard and tin 
packages, chemical, textile and food branches. The Goleniów Industrial Park (GIP) is a fully developed area of 305 ha, designed to suit the needs of industrial production and services. In the GIP, a Special Economic Zone is located, which is a subzone of the Kostrzyń-Stubice Special Economic Zone. A very important part of the spatial policy is disposal of commune estates.

dr Maciej J. Nowak

Zachodniopomorski Uniwersytet Technologiczny w Szczecinie

e-mail: maciej.nowak@e-ar.pl 